UDC 81.373 .43

DOI https://doi.org/10.32838/2663-6069/2020.3-1/34

Sandyha L. O.

Taras Shevchenko National University of Kyiv

Oliinyk I. $V$.

Taras Shevchenko National University of Kyiv

Sviatiuk Yu. $V$.

Taras Shevchenko National University of Kyiv

\title{
ENGLISH GREEN NEOLOGISMS REFLECTING NEW TRENDS IN SUSTAINABLE DEVELOPMENT
}

The present article investigates new ecological trends reflected in numerous neologisms which have recently entered the English language. We define neologisms as newly coined or existing words or word combinations which name new concepts or phenomena and which are moderately used by most representatives of a given society. As the number of people supporting sustainable development and following a healthy lifestyle is growing, the English vocabulary is constantly being enriched with new examples of neologisms depicting a green lifestyle and sustainable business running. Surprisingly, the neologisms coined in the sphere of sustainable development have not been investigated as a complex phenomenon. Thus, the aim of the current research is to focus on the neologisms denoting various types of sustainable initiatives, namely waste reduction (litter vigilantes, pickers, plogging, sharing economy), recycling (infinity recycling, precycling), running a business (greentailing), ecological housing (microflats, tiny houses, yarden), dieting (demitarian, seaganism, pescatarians), farming (regenerative agriculture, mob grazing), shopping (Green Friday), inventing new sources of energy (bionic mushroom), traveling (flight shaming), construction (corkitecture) etc. Attention is given to the neologisms naming unethical or negative ecological practices (dirty camping, urban creep, greenwashing) as well. The emphasis is also laid on the study of the derivational potential of the neologisms under consideration. Such word-forming mechanisms as blending, compounding, prefixation, repurposing and clipping are considered. Within the framework of our research compounding has turned out to be the most productive word-forming mechanism (54\% of the neologisms under consideration), blending (25\%) and prefixation (11\%) are popular mechanisms as well, whereas repurposing, borrowing, clipping and conversion are unproductive. Finally, general inferences are made and suggestions for further linguistic research are given.

Key words: ecological neologism, blending, compounding, prefixation, repurposing, clipping, borrowing, conversion.

Nowadays there is a growing world community of ecologically-minded individuals who are keen to make their small yet valuable contribution towards saving our planet from deleterious human activity. The scope of sustainable initiatives is varied and encompasses a large array of initiatives. Waste reduction activists make the world a cleaner place, a growing community of vegetarians and people who consume less meat and eat more plant-based food are changing their dietary patterns to reduce carbon footprint; individuals who are engaged in scientific research aim to invent a wider range of sustainable sources of energy etc. Naturally, such new ecological practices and phenomena named by corresponding neologisms are the object of current research.
We define neologisms as newly coined or existing words or word combinations which name new concepts or phenomena and which are moderately used by most representatives of a given society.

Neologisms found in various spheres of life have been studied by different researchers worldwide, namely J. Algeo, A. Lehrer, K. Maxwell, A. Metcalf, R. Fischer, P. Hohenhaus, B. Aarts and A. Mcmahon, P. Štekauer, K. Karpova and many others, all of whom have investigated various spheres of life where neologisms are born. For instance, B. Aarts and A. Mcmahon researched neology comprehensively in various languages, K. Karpova studied food-related neologisms, A. Lehrer focused on word-formation techniques.

The aim of our research is to study neologisms coined in the sphere of ecology and sustainable 
development as a complex phenomenon, analyze their word-formation techniques.

Data and Methodology. Throughout our research 61 neologisms designating sustainable development phenomena were selected by sampling from the following lexicographic sources: About Words - Cambridge Dictionaries Online Blog [2] and Buzzword Archive - Macmillan Dictionary [4]. The neologisms under investigation have also been taken from reputable Internet sites, namely https:// neologisms.rice.edu, http://www.investopedia. com, https://www.thetimes. co.uk, https://www. businessinsider.com, https://www.theguardian.com.

The research methods are grounded on the aim, objectives of the study and the collected data. Thus, the following linguistic methods have been utilized: 1) structural (to research the derivational potential of the neologisms denominating new ecological phenomena and initiatives; to analyse blending, compounding and prefixation and other techniques in forming ecological neologisms in the modern English language and determine which of them is the most productive in the sphere of green neology); 2) semantic (to study the lexical meanings of the ecological vocabulary); 3) classification and systematisation (to group the neologisms under investigation into certain categories taking into account their meanings).

In accordance with the 2015 Global Corporate Sustainability Report made by Nielsen, a global performance management company which offers comprehensive outlook of 'what consumers Watch and Buy', $66 \%$ out of 30,000 customers from 60 countries claimed they would prefer to purchase green brands even if they were more expensive than non-ecological products, which is up 55\% year-on-year. At the same time the figure is $73 \%$ for polled millenials, proving that the representatives of the younger generation are more ecologically-minded. The survey has also showed that a person's income is not a decisive factor when it comes to choosing sustainability over additional expenses as eco-mindedness is consistent across the board. Therefore, should large global brands avoid following sustainability protocols in their production processes, they risk losing their reputation and, as a result, profits [11].

Many companies have recently started using the ecological approach to doing business and are now selling green products to like-minded consumers, the practice being called greentailing (blending green+retailing) and the sellers greentailers (blending green+retailers) [4]. A. Lehrer believes that blending is a remarkably productive word- formation technique in modern English, French, German etc (8, c. 360).

Not all companies, however, appear to be frank in their environmentally friendly activities, some big corporations only pay lip service to being green. Their main aim is to, firstly, attract eco-minded customers, secondly, obtain government subsidies to expand. Such environmental malpractice is designated by the neologism greenwashing (blending green+brainwashing) [14].

A. McMahon states that affixation and compounding are the most generative word-formation techniques in the English language [10, c. 196]. An opposite to Black Friday, a neologism Green Friday formed by means of compounding [2] is the answer to blind consumerism as it is the movement which encourages customers to either purchase fewer products or choose sustainable products with an ethical supply chain. Therefore, changing one's shopping habits is one of the steps ordinary citizens can take to start from themselves and make a difference to the ecological situation.

D. Minkova and R. Stockwell claim that new lexemes are seldom coined out of nowhere, they are often based on some existing word (or its part) [12, c. 12]. This approach can be demonstrated by a new initiative called precycling (prefixation pre+recycling) [2], which is a more ecologicallyfriendly alternative to recycling. Precycling offers a variety of measures humans can take to minimize the harmful impact on the environment namely by purchasing unpacked goods or those with little packaging or in bulk, reusing shopping bags, making bread or yoghurt at home to avoid unnecessary packaging, stop buying the items that are not of particular importance and that one can easily do without and buy high-quality, durable and longlasting products. One more new type of recycling called infinity recycling (compounding) [2] stands for a new technology of recycling plastic whose quality doesn't deteriorate, thus it can be recycled infinitely.

One more way to make our streets cleaner is to start from ourselves and become the people who pick up litter in public places on their own initiative. The neologisms litter vigilantes (compounding) [2] and pickers (repurposing) [2] testify the trend's popularity with city dwellers.

Yu. Zatsnyi claims that over the last decade the English language has been replenishing its vocabulary at the expense of its own language resources in most cases [1, c. 20]. However, the neologism plogging (borrowing+blending) [4] is an example of a blend in which a borrowed word is the first component. The new global fitness 
trend unites eco-minded people who pick up litter while jogging. The leisure activity is a Swedishborn initiative which is sweeping the whole world and the word itself is a blend of a Swedish verb plocka (to pick) and the noun jogging. What is interesting, ploggers (borrowing+blending) [4] tend to burn more calories than traditional joggers as they need to bend down to lift trash thus providing an efficient workout for their core and legs.

Unfortunately, not all people are ecologicallyminded yet, there are still those who leave rubbish behind themselves after living in a tent, which is called dirty camping (compounding) [2].

Technological progress generates a growing demand for new electronic equipment with landfills full of yesterday-new computers and mobile phones, the latter being called $\boldsymbol{e}$-waste (prefixation) [2].

On the other hand, the neologisms sharingeconomy, access economy, collaborative economy, mesh [4] and collaborative consumption (compounding all the five) [7] describe a newly-invented economic model of peer-to-peer lending market under which underused physical assets, such as tools, cars, apartments etc are rented out when the owner does not need them. On the one hand, sharing economy brings a lot of advantages for the environment as people do not need to buy and stock the things they might need only once a year. Moreover, ridesharing services, for instance, Uber, help to cut down on emissions and reduce congestion thus offering a more sustainable driving experience. However, such kind of economy fosters tax evasion as individual lenders' activity is in no way regulated by authorities [5].

The processes of nature's conservation are oriented towards the protection of animals as well. Reintroduction of animals which previously inhabited a particular habitat but were forced to leave it is called rewilding (prefixation) [2].

The scientists who are searching for sustainable sources of energy have invented a bionic mushroom (compounding) [4]. This new alternative to fossil fuels produces electricity due to special energygenerating bacteria it is covered with. Other scientists modify some of bees' genes so that the insects receive immunity to viruses and pesticides, such a new breed of bees is called frankenbees (blending Frankenstein+bees) [2].

Overpopulation reflected in a neologism urban creep (compounding) [2] and astronomic prices for accommodation in megalopolises have led to a rise in microflats (prefixation) [2], i.e. very small apartments, found in big cities. Like-minded residents may also move to tiny houses (compounding) [2], i.e. small homes measuring less than 37 square metres. Such home owners are supporters of the Tiny House movement who follow a simple lifestyle and don't pay much attention to material values.

Furthermore, as cities become overcrowded, and more and more houses and roads are being built it is not surprising that public parks and gardens become a thing of the past and to somehow compensate the loss of green space, pocket parks (compounding) [2], i.e. small parks created on small pieces of land are being constructed. Similarly, those people who own private houses and dream to have their own green place to relax start transforming their back yards into small gardens, hence the neologism yarden (blending yard +garden) [2].

Moreover, teleworking has already become a sustainable and a stress-free alternative to commuting with shoffices (blending shed+offices) [2], i.e. former garden sheds functioning as telecommuters' workstations. However, modern shoffices are not moss and cobweb-covered wooden huts where old rusty tools are kept. On the contrary, they are usually equipped with modern conveniences, in particular floor-to-ceiling windows, high-speed wifi, in-built showers and even underfloor heating [6].

One more category of people who want to make a positive impact on the environment start building super-homes (prefixation) [2], the latter being modern well-insulated houses which allow their owners to cut down the consumption of electricity. Therefore, we can see a number of 'sustainable' neologisms which concentrate on smaller yet greener innovations.

Top brands follow suit by introducing new sustainable materials. For instance, the Danish toy giant Lego has started to manufacture its products and packaging using plant-based materials, in particularnew blocks are $98 \%$ sugar-cane polyethylene [15]. One more ecological material used for building is cork which has given birth to a neologism corkitecture (blending cork+architecture) [13]. Cork's advantages, such as water resistance, good insulation and compression properties make it a wonderful material for sustainable construction.

It would be no exaggeration to say that combatting carbon emissions is one of the priorities humanity is setting nowadays. The process covers many directions and activities and involves every citizen of Earth.

It is worth mentioning that the number of those who embrace new types of diets is growing. Be it for animal cruelty reasons, health or environmental concerns or weight loss a new cohort of vegetarians of various types has appeared and it is gaining new followers at an astonishing speed. 
Vegetarianism and veganism have long become widespread lifestyles for many animal lovers. However, a new category of eaters who cannot stop eating meat once and forever may try going on a demitarian (prefixation+clipping) [2] diet. Thus, by restricting the amount of meat and animal products they consume, demitarians (prefixation+clipping) [2] will reduce the environmental impact of their consumption patterns.

Seaganism (blending sea+veganism) [2] represents a new trend in sustainable dieting when its proponents, seagans (blending sea+vegans) [2], don't consume meat, dairy products and eggs, but make an exception for seafood and sustainable fish. Not only does it make people's diets more varied, but nutritional too as seafood is rich in protein and omega 3 fats which a traditional vegan diet usually lacks. Interestingly, seaganism's creators are well-known, the latter being US food writers Amy Cramer and Lisa McComsey who invented the term in their cookery book Seagan Eating in 2016 [4].

Pescatarians (also pescetarians) (blending) [4] also choose fish and seafood as their staple diet and do not eat meat at all. However, unlike seagans, pescatarians can consume dairy products, eggs, honey, gelatin and non-vegan liquors.

There is also a new kind of veganism when its adepts, bivalvegans (blending bivalve+vegan) [2] consume only certain types of mussels that do not possess a nervous system and thus do not feel pain.

Sometimes ecological neologisms are born in parliament and their 'birth' takes place amidst a laborious political argument. In April 2019 the European Parliament's Committee on Agriculture and Rural Development enacted new food-labeling regulations which ban the usage of meat nomenclature to name vegetarian products. Thus, veggie burgers, i.e. flat round-shaped pressed vegetables, seeds etc, which have existed for some time as an alternative to meat hamburgers, have been recently renamed veggie discs (compounding) by the European parliament. The decision is explained by a desire to reserve meat terms for meat products exclusively, therefore burgers, sausages, steaks and escalopes must not be used for labeling plantbased foods as people must not be deceived about what they are eating. Similarly, in 2017 the European court of justice passed a regulation under which soya and tofu cannot be marketed as dairy products, the only exemptions being cocoa butter, salad cream and coconut milk [3].

One more sustainable and ethical alternative to animal meat is the so called motherless meat [2], cultured meat, lab-grown meat, cell-based meat, clean meat or in-vitro meat (compounding). All the neologisms name a new type of meat which does not come from a live animal and has been grown in a laboratory from cells and can include vegetables, soya, legumes or other meat alternatives which looks, tastes like meat and possesses the same health benefits. Scientists, environmentalists and health organization are concerned by the carbon footprint and the impact on animals that the production of conventional meat causes [9].

Environmentally-minded citizens choose one more alternative that may reduce the amount of food waste which is called freeganism (blending free+veganism) [4]. Freegans (blending free+vegans) [4] are anticonsumerists who collect and consume thrownaway food from supermarket garbage containers and bakery bins which would otherwise has been transported to a landfill. By doing so, they protest against unnecessary waste and the consequent deleterious impact on the environment. A more extreme embodiment of freeganism is plate scraping (compounding) [4] or table diving (compounding) [4] with freegans going to restaurants to eat leftovers. The freegans who indulge in such practices are called plate scrapers (compounding) [4] or table divers (compounding) [4].

Some people go even further in their nutrition habits. A new breed of humans who believe that all the nutrients can be received from air with the help of special breathing exercises and thus they can stop consuming solid food are called breatharians (blending) [2].

Speaking about responsible farming, there is a number of new trends whose followers aim to maintain the soil fruitful. Thus, regenerative agriculture (compounding) [2] is a general term which describes a farming method whose goal is improving the state of soil. Another green farming neologism denotes a practice of perpetual relocation of a herd of animals to new small areas of grass for a short period of time to allow the grass to recover and is called mob grazing (compounding) [2].

A neological noun net zero [4] (conversion, adjective net-zero) describes a situation when the quantity of carbon emissions released into the atmosphere does not exceed the quantity of removed carbon, as a result of which the ecological situation at least remains at the same level. It is therefore not surprising that the damage humanity has been causing to the environment returns to us in the form of multiple illnesses and diseases. For instance, Londoners may catch a new type of cold caused by air pollution called London throat (compounding) [2]. 
Water and marine life pollution is a serious issue as well. The neologism revealing a new problem is ghost gear (compounding) [2]. The latter stands for fishing equipment abandoned in the ocean and thus harming the environment as its decomposition takes hundreds of years.

As a result of climate change new professions are born to prevent deleterious consequences of human activity. A new job is the one of a tidewater architect (compounding) [2] who plans and designs parts of cities and towns in order to protect them from rising tides caused by changes in climate. Ecologists whose aim is to stop or decrease the coastline's erosion with the help of bringing an immense quantity of sand to a certain beach are involved in sandscaping (blending sand+landscaping) [2].

Not only is our planet polluted, the byproducts of human activity can be found in space. For instance, a neologism space grease (compounding) [2] stands for molecules of oily carbon found in space.

Sometimes, however, ecological initiatives can become too strict and categorical. For instance, travelling by plane has recently become one of the culprits of ecological damage to the environment, thus, flight shaming (compounding) [2], i.e. the act of accusing someone of flying is gaining ground.

Traveling may also be treated negatively by the residents of places which are visited by too many tourists, thus causing inconvenience for locals, the phenomenon being known as overtourism (prefixation) [4]. On the other hand, undertourism (prefixation) [2] characterizes a situation when a holiday destination does not receive enough tourists, thus decreasing the income of the local hospitality industry.

Some people make huge sacrifices to save the planet, in particular, there is a new category of women, birth strikers (compounding) [2] who choose not to have children in order not to increase the world's population which is already too big.

On the flip side, there is a new category of irresponsible businesspeople called climate criminals (compounding) [2], i.e. individuals or organizations whose activities have caused considerable harm to the environment.

Conclusions. Thus, the practical focus of our research is on modern ecological trends and initiatives reflected in the English neologisms. Such abundance of neologisms proves that the world community is actively involved in the process of sustainable development of our planet. Moreover, the span of green activities is diverse and involves many businesses and individuals worldwide. The spheres in which such neologisms are created include waste reduction, running a business, ecological housing, dieting, farming, shopping, traveling, cleaning, recycling, inventing new sources of energy, construction, fighting climate change etc. The neologisms naming unethical or negative ecological practices are also considered.

The statistics gained in our research support A. McMahon's aforementioned statement about compounding being the most productive wordformation technique in the English language (33 green neologisms out of 61 , i.e. 54\%). The green neologisms coined by means of blending (15 units) account for $25 \%$ of the total, prefixation $-11 \%$ (7), the combination of borrowing and blending, and prefixation and clipping both take up 3\%, whereas repurposing and conversion take part in the formation of only one neologism each.

Our future research will be devoted to other productive spheres in which modern neologisms are formed, in particular culture, health, modern technologies, tourism etc. What is more, other wordforming patterns, namely, acronymy, conversion, clipping etc. will be investigated in detail.

\section{References:}

1. Зацний Ю. А. Способи та механізми створення лексико-фразеологічних інновацій англійської мови (2009-2019 рр.). Нова філологія. 2020. Вип. 79. С. 20-26.

2. About Words - Cambridge Dictionaries Online Blog (n.d.). URL: https://dictionaryblog.cambridge.org/ (retrieved 27 July, 2020).

3. Boffey D. 'Veggie discs' to replace veggie burgers in EU crackdown on food labels. 2019. URL: https://www.theguardian.com/food/2019/apr/04/eu-to-ban-non-meat-product-labels-veggie-burgers-andvegan-steaks (retrieved 27 July, 2020).

4. Buzzword Archive - Macmillan Dictionary (n.d.). URL: http://www.macmillandictionary.com/buzzword/ entries/legsie.html (retrieved 30 July, 2020).

5. Chappelow J. Sharing economy. 2020. URL: http://www.investopedia.com/terms/s/sharing-economy.asp (retrieved 21 June, 2020).

6. Clatworthy B., Williams A. Step into my 'shoffice' shed - the new garden must-have. 2018. URL: $\quad$ https://www.thetimes.co.uk/article/step-into-my-shoffice-shed-the-new-garden-musthave-tsvr7s0sz (retrieved 25 July, 2020). 
7. Kessler S. The "Sharing Economy" Is Dead, And We Killed It. 2015. URL: http://www.fastcompany.com/ 3050775/the-sharing-economy-is-dead-and-we-killed-it (retrieved 13 August, 2020).

8. Lehrer A. Identifying and interpreting blends: An experimental approach. Cognitive Linguistics. 1996. Vol. 7. Issue 4. P. 359-390. URL: https://doi.org/10.1515/cogl.1996.7.4.359 (retrieved 10 May, 2020).

9. Lyons S. Marketing can affect our attitudes and willingness to eat lab-grown meat. 2019. URL: https://www.abc.net.au/news/science/2019-07-03/marketing-cultured-meat/11271232 (retrieved 20 July, 2020).

10. McMahon A. S. Understanding Language Change. Cambridge and New York : Cambridge University Press, 1994. 361p.

11. McCaskill A. Consumer-goods' brands that demonstrate commitment to sustainability outperform those that don't. 2015. URL: https://www.nielsen.com/ssa/en/press-releases/2015/consumer-goods-brands-thatdemonstrate-commitment-to-sustainability-outperform/ (retrieved 12 June, 2020).

12. Minkova D., Stockwell R. English Words: History and Structure. Cambridge, England : Cambridge University Press, 2009. 221 p.

13. Slessor C. Cork house review - barking up the right tree. 2019. URL: https://www.theguardian.com/ artanddesign/2019/jul/28/cork-house-review-eton-stirling-prize-matthew-barnett-howland-dido-milne-oliverwilton (retrieved 5 August, 2020).

14. The Rice university neologisms database (n.d.). URL: https://neologisms.rice.edu/index.php? $\mathrm{a}=$ term\&d=1\&t=17561 (retrieved 17 August, 2020).

15. Woloszyk A., Moynihan R. LEGO hope to make most of their products from sustainable sugarcane by 2030. 2018. URL: https://www.businessinsider.com/lego-go-eco-friendly-with-blocks-made-fromsugarcane-2018-8 (retrieved 21 August, 2020).

\section{Сандига Л. О., ОЛійНИк І. В., Святюк Ю. В. АНГЛІЙСЬКІ ЕКОЛОГІЧНІ НЕОЛОГІЗМИ ЯК ВІДОБРАЖЕННЯ НОВІТНІХ ТЕНДЕНЦІЙ У СЕСТЕЙНОВОМУ РОЗВИТКУ}

У статті досліджуються новітні екологічні тендениії, відображені в низиі сучасних англомовних неологізмів. Неологізми визначаються як новостворені або такі, що вже існують у мові лексеми або словосполучення, які називають нові поняття іякі помірно використовуються більшістю представників визначеного суспільства. 3 огляду на зростання кількості людей, які підтримують стійкий розвиток та ведуть здоровий спосіб життя, англійська лексична система постійно збагачується новими прикладами неологізмів для позначення екологічного способу життя та ведення бізнесу. Щоправда, дослідження таких неологізмів як комплексного феномену ще не проводились. Таким чином, метою даного дослідження є сфокусуватися на неологізмах, щцо позначають різноманітні види екологічних ініиіатив, а саме зменшення сміття (litter vigilantes, pickers, plogging, sharing есопоту), переробку відходів (infinityrecycling, precycling), управління бізнесом (greentailing), екологічнежитло (microflats, tiny houses, yarden), харчування (demitarian, seaganism, pescatarians), фермерство (regenerative agriculture, mob grazing), покупки (Green Friday), винайдення нових джерел енергії (bionic ти shroom), подорожування (flight shaming), будівництво (corkitecture) тощо. Увага також присвячується неологізмам, які називають неетичні або негативні екологічні практики (dirty camping, urban creep, greenwashing). Робиться наголос на вивченні словотвірного потенціалу екологічних неологізмів, зокрема, вивчаються такі словотвірні механізми, як телескопія, словоскладання, префіксація, зміна значення та усічення. У межах дослідження словоскладання виявилось найпродуктивнішим словотвірним механізмом (54\% досліджених неологізмів), телескопія (25\%) та префіксачія (11\%) є також популярними, на відміну від зміни значення, запозичення, усічення та конверсії. Наприкіниі статті представлені загальні висновки і пропозиції щчодо подальщих лінгвістичних розвідок.

Ключові слова: екологічний неологізм, телескопія, словоскладання, префіксачія, зміна значення, усічення, запозичення, конверсія. 